\title{
A New Proposition of Business Model Innovation: Anteceding Managerial Competencies
}

\author{
Lejla Turulja
}

The University of Sarajevo, School of Economics and Business, Bosnia and Herzegovina

Selma Smajlović

The University of Tuzla, Faculty of Economics Tuzla, Bosnia and Herzegovina

\begin{abstract}
Knowledge, competencies, and human capital are the cornerstones of business innovation. Generating innovation alone is not a guarantee of success in the market, but it is necessary to successfully manage innovation, which requires managers' expertise and specific competencies. The paper focused on analyzing the impact of several managerial competencies on improving the new proposition dimensions of the business model innovation. The business model innovation consists of new creation innovation, new proposition innovation, and value capture innovation. This paper analyses the new proposition innovation segment that relates to solutions for customers and how they are offered; it consists of the dimensions of new offerings, new customers and markets, new channels, and new customer relationships. The research was conducted among managers of companies from several industries, who evaluated their competencies, namely analytical and innovative, their ability to recognize opportunities, their tenacity, and passion for work, as well as new proposition innovation of business model innovation. The findings suggest that each of the managerial competencies is influential in some way but that they do not all affect each dimension of a new proposition of business model innovation.
\end{abstract}

Keywords: managerial competencies, business model innovation, the new proposition

JEL classification: $032, \mathrm{M} 1$

Paper type: Research article

Received: Mar 17, 2021

Accepted: Sep 2, 2021

DOI: $10.54820 / C L D P 2350$ 


\section{Introduction}

Business Model Innovation (BMI) is the process of developing new mechanisms for producing, distributing, and collecting value to get consumers to pay for it and transform it into profit (Bocken et al., 2020). In a volatile business climate, BMI is regarded as critical to a company's competitiveness and survival (Bouncken et al., 2016; Futterer et al., 2018). Specifically, the evolution of information technology (IT) and its influence on the transformation of business processes, as well as the goods and services themselves, compels organizations to continually re-examine and enhance their business model.

Various BMI conceptualizations are present in the literature. Despite conceptual variations amongst scientists in different study areas, several aspects are shared by most definitions of the business model. According to Zott et al. (2011), they are classified as follows:

- There is general agreement that a business model is a separate unit of analysis distinct from the product, company, industry, or network contained within the firm, but with limits that are larger than the companies.

- Business models stress a comprehensive, systemic approach to understanding how firms "do business."

- The actions of the firm and its partners are important in the various business conceptualizations. Both value creation and value appropriation are attempted to be explained by business models.

More in-depth research was performed to determine the content components of the business model. According to Zott et al. (2010), three fundamental aspects of a business model are content (activities to be performed), structure (how and on what basis the activities are connected), and governance (who implements those activities). Spieth et al. (2016) consider the business model to be a holistic approach that incorporates three key integrative dimensions: value offering, value architecture, and revenue model. First, the value-offering dimension consists of the following elements of the business model: target customers, products and service offerings, and competitive positioning. These elements serve to explain to whom the firm provides what benefits, and how it thus differs from its competition. Second, to explain the value creation architecture, Spieth et al. (2016) identified four elements of the business model: key competencies and resources, internal value creation, external value creation network, and distribution. These elements further define the resources and competencies in the process of creating a value proposition of the company, what activities inside and outside the company were used in the process of value creation and how the created value proposition was delivered to the target customers. The third dimension of the business model, the revenue model consists of the last two elements, revenue, and cost mechanism. These elements serve to explain how a company makes money, highlighting the types and sources of revenue, as well as the cost structure (Spieth et al., 2016).

Clauss (2017) considers business model innovation as a multidimensional construct consisting of three dimensions:

- Value creation dimension - specifies how and with what resources businesses generate value along the value chain, utilizing the resources and capabilities of organizational processes;

- Dimension of value proposition - defines solutions for customers and the way of presenting the offer to end customers;

- Value retrieval dimension - defines how the company generates revenues that cover costs and makes a profit. 
According to Clauss (2017), business model innovation represents a change in each of these dimensions or at least in one of them. This paper aims to analyze the value proposition dimension of BMI, which consists of the following sub-dimensions:

- New offerings describe what a firm offers to address its customers' issues or better fulfill their requirements, and it relates to the creation of a new product or service or the application of new technology.

- New markets refer to new client groups or market segments in which the firm provides its products or services. This dimension entails either redefining existing markets or entering new ones.

- New channels are associated with new methods of providing value to endusers.

- Customer relationships imply a company's capacity to enhance or establish new relationships with its customers, given that these relationships are a key source of information regarding changes in the environment and market demands.

The effectiveness of business models depends on management that can make quick decisions actively learning at multiple levels, building commitment, and engaging conflict (Smith et al., 2010). Managers manage the present while creating the future while assessing and improving the business model. This is why managers' knowledge and skills are important to BMI. Several studies have recognized and analyzed this relationship. Lumpkin et al. (2011) examined the influence of previous work experience as well as the ability to detect business opportunities on BMI. Some research, on the other hand, has found risk-taking abilities (Dewald et al., 2010), managerial and entrepreneurial skills, and managerial connections as predictors of BMI (Guo et al., 2013).

In this regard, this study aims to analyze the impact of managerial competencies on the value proposition dimension of BMI. The competencies that will be analyzed in this paper are opportunity recognition, analytical thinking, innovativeness, tenacity, and passion to work. Consequently, the findings will provide findings that reflect the contribution of managers' competencies to the company's business performance as reflected in the value proposition of innovation of the business model.

\section{Hypotheses Development}

Numerous studies have found that BMl is a key source of competitive advantage and business results for organizations (Guo et al., 2013). However, it is vital to recognize that $\mathrm{BMI}$ does not originate directly, but rather requires strong ability, talents, and competent managers to develop successful BMI (Anwar et al., 2019). Business models are designed to achieve economic value through the exploitation of entrepreneurial opportunities (George et al., 2011). Managers through the effective combination and design of internal and external resources to exploit opportunities contribute to this goal (Zott et al., 2010).

Previous research suggests that managers' skills and capabilities have a direct and positive impact on business model innovation. Guo et al. (2013) empirically confirm that the managerial and entrepreneurial skills and managerial connections of top managers significantly lead to business model innovations. Anwar et al. (2019) discuss the importance of managerial skills in adapting the business to a competitive environment and confirm that managers with extraversion, likeability, and openness to personal experience have a significant positive impact on business model innovation. Following these findings, we contend that managers' skills and competencies impact firms' new proposition of BMl because managers make 
decisions and strategically lead businesses. The competencies analyzed in this paper are:

- Opportunity recognition - includes research, development, and evaluation of high-quality opportunities available in the market and the environment (Man, 2002). Man (2002) regards opportunity recognition as a significant dimension of managerial entrepreneurial competencies.

- Analytical competencies - according to Man et al. (2008), refer to the application and integration of ideas, as well as the monitoring of their implementation.

- Innovative competencies - relate to the capacity to engage in and promote new ideas and creative processes (Chinwendu et al., 2021).

- Tenacity - often known as persistence, is the ability to maintain goal-directed action and energy in the face of adversity (Baum et al., 2004).

- Passion - work-related passion refers to sentiments of love, connection, and desire for one's job (Baum et al., 2004).

Consistent with the preceding discussion, we hypothesize in this study that the aforementioned competencies also influence new proposition of BMI, as reflected by the following hypotheses:

- Hypothesis 1: Manager's opportunity recognition competencies are related to the firm's new proposition dimension of business model innovation.

- Hypothesis 2: Manager's analytical competencies are related to the firm's new proposition dimension of business model innovation.

- Hypothesis 3: Manager's innovative competencies are related to the firm's new proposition dimension of business model innovation.

- Hypothesis 4: Manager's tenacity is related to the firm's new proposition dimension of business model innovation.

- Hypothesis 5: Manager's passion for work is related to the firm's new proposition dimension of business model innovation.

Selected competencies are regarded as entrepreneurial competencies, i.e. the entrepreneur's overall ability to successfully perform a job function (Man, 2002). Earlier research has found that certain entrepreneurial characteristics of managers have an impact on business success (Mitchelmore et al., 2010). In this regard, the hypothesis proposed poses that managers with research, development, and assessment abilities for high-quality possibilities accessible on the market and in the environment would result in the generation of new propositions for the firm $(\mathrm{H} 1)$. Also, a manager who is capable of applying and implementing ideas will contribute to the company's new propositions of BMI (H2). Managers who participate in and support new ideas and creative processes are more likely to contribute to the firm's new propositions (H3). Furthermore, managers' capacity to maintain goal-directed action and maintain energy in the face of challenges will result in new propositions for the firm (H4). Finally, a manager who has a sense of love and connection to his work will be more committed to developing new propositions for the company $(\mathrm{H} 5)$.

\section{Methodology}

Data for this research were collected by surveying this manager in the active medium and large companies in Bosnia and Herzegovina. Following the practice of previous similar studies, top managers were selected as adequate respondents given that they are familiar with the ideas and values within the organization (Limaj et al., 2019). The sample consisted of 267 medium and large companies with an average of 27.27 years (from the day of establishment). $85 \%$ of companies are privately owned, $5 \%$ state-owned, and $7 \%$ mixed-ownership. During the process, an 
initial invitation to participate in the research was sent, followed by two reminders. 1,358 people accessed the link, while 321 people filled out a questionnaire to submit answers. However, during the data screening process, 54 surveys were excluded from the analysis due to the missing values (Hair et al., 2018).

Table 1

Measurement items

\begin{tabular}{|c|c|}
\hline Dimension & Indicators \\
\hline \multirow{3}{*}{$\begin{array}{l}\text { Opportunity } \\
\text { recognition }\end{array}$} & Identify goods or services customers want \\
\hline & Perceive unmet consumer needs. \\
\hline & Actively look for products or services that provide real benefit to customers. \\
\hline \multirow{3}{*}{$\begin{array}{l}\text { Analytical } \\
\text { skills }\end{array}$} & Apply ideas, issues, and observations to alternative contexts. \\
\hline & Integrate ideas, issues, and observations into more general contexts. \\
\hline & Monitor progress toward objectives in risky actions \\
\hline \multirow[t]{3}{*}{ Innovative } & Look at old problems in new ways. \\
\hline & Explore new ideas. \\
\hline & Treat new problems as opportunities. \\
\hline \multirow[t]{4}{*}{ Tenacity } & I can think of many times when I persisted with work when others quit. \\
\hline & I am able to work a lot more than most people I know. \\
\hline & I am able to do challenging and demanding work for a long time. \\
\hline & $\begin{array}{l}\text { When something goes wrong, I always try to analyze the cause of the } \\
\text { problem and approach its solution. }\end{array}$ \\
\hline \multirow[t]{4}{*}{ Passion } & Most of the satisfaction in my life comes from the work I do. \\
\hline & $\begin{array}{l}\text { I often think about my job, even while doing some other private life } \\
\text { activities that have nothing to do with work. }\end{array}$ \\
\hline & I find it difficult to get away from work to fulfill some other obligations. \\
\hline & I work a lot because I love my job. \\
\hline \multirow{2}{*}{$\begin{array}{l}\text { New } \\
\text { offerings }\end{array}$} & We regularly address new, unmet customer needs. \\
\hline & $\begin{array}{l}\text { Our products or services are very innovative in relation to our competitors. } \\
\text { Our products or services regularly solve customer needs, which were not } \\
\text { solved by competitors }\end{array}$ \\
\hline \multirow[t]{2}{*}{ New markets } & We regularly address new, unserved market segments. \\
\hline & $\begin{array}{l}\text { We are constantly seeking new customer segments and markets for our } \\
\text { products and services. }\end{array}$ \\
\hline \multirow{3}{*}{$\begin{array}{l}\text { New } \\
\text { channels }\end{array}$} & We regularly utilize new distribution channels for our products and services. \\
\hline & $\begin{array}{l}\text { Constant changes of our channels have led to improved efficiency of our } \\
\text { channel functions. }\end{array}$ \\
\hline & We consistently change our portfolio of distribution channels. \\
\hline \multirow{2}{*}{$\begin{array}{l}\text { New } \\
\text { customer } \\
\text { relationships }\end{array}$} & $\begin{array}{l}\text { We try to increase customer retention by new service relationships } \\
\text { offerings. }\end{array}$ \\
\hline & $\begin{array}{l}\text { We emphasize innovative/modern actions to increase customer retention. } \\
\text { We recently took many actions in order to strengthen customer } \\
\text { relationships. }\end{array}$ \\
\hline
\end{tabular}

Source: Man et al. (2008), Baum et al. (2004), Clauss (2017)

\section{Results}

The PLS-SEM estimation technique was used for data analysis, with the following two steps: (i) the measurement model was evaluated, and (ii) an analysis of structural relationships (hypotheses) was performed. The analyzed constructs are all first-order reflective, and testing for internal consistency reliability, convergent, and discriminant validity was performed. Reliability was tested using composite reliability $(C R>0.7)$. Convergent validity was tested by checking factor loadings of all indicators ( $>0.7$ ) and using the average variance extracted indicators (AVE $>0.5$ ) 
(Hair et al., 2018). Finally, discriminant validity was tested using the Fornell-Larcker criterion (Fornell et al., 1981). This criterion was met when the square root of the AVE value is greater than its highest correlation with any other construct. In addition, the Heterotrait-Monotrait Ratio (HTMT) and the ratio were checked with values below 0.9 indicating the determination of discriminant validity.

The CR and AVE values are shown in Table 2; all CR values are more than 0.7, and all AVE values are greater than 0.5 , indicating the reliability and convergent validity of the measurement model. Table 3 shows the square root of the AVE value on the diagonal, while the correlations of the constructs are below. As seen in the table, all values on the diagonal are larger than the correlation values, supporting the measurement model's discriminant validity. Finally, Table 4 demonstrates that all values are smaller than 0.9 , which further confirms the discriminant validity.

Table 2

Internal consistency and convergent validity

\begin{tabular}{lrrrr}
\hline & $\begin{array}{c}\text { Cronbach's } \\
\text { Alpha }\end{array}$ & rho_A & CR & AVE \\
\hline Opportunity & 0.878 & 0.888 & 0.925 & 0.803 \\
Analytical & 0.857 & 0.860 & 0.913 & 0.779 \\
Innovative & 0.857 & 0.859 & 0.913 & 0.777 \\
Tenacity & 0.893 & 0.895 & 0.921 & 0.701 \\
Passion & 0.849 & 0.855 & 0.898 & 0.687 \\
New Offerings & 0.806 & 0.810 & 0.886 & 0.722 \\
New Markets & 0.769 & 0.770 & 0.897 & 0.813 \\
New Channels & 0.925 & 0.925 & 0.952 & 0.869 \\
New Cust Relat & 0.827 & 0.829 & 0.896 & 0.743 \\
\hline
\end{tabular}

Note: CR is composite reliability; AVE is the average variance extracted (AVE)

Source: Authors' work

Table 3

Discriminant validity (Fornell-Larcker criterion)

\begin{tabular}{|c|c|c|c|c|c|c|c|c|c|c|}
\hline & & 1 & 2 & 3 & 4 & 5 & 6 & 7 & 8 & 9 \\
\hline 1 & Analytical & 0.882 & & & & & & & & \\
\hline 2 & Innovative & 0.715 & 0.882 & & & & & & & \\
\hline 3 & New Channels & 0.392 & 0.344 & 0.932 & & & & & & \\
\hline 4 & New Cust Relat & 0.310 & 0.303 & 0.598 & 0.862 & & & & & \\
\hline 5 & New Markets & 0.357 & 0.415 & 0.663 & 0.688 & 0.901 & & & & \\
\hline 6 & New Offerings & 0.289 & 0.360 & 0.548 & 0.728 & 0.701 & 0.850 & & & \\
\hline 7 & Opportunity & 0.764 & 0.588 & 0.357 & 0.322 & 0.377 & 0.309 & 0.896 & & \\
\hline 8 & Passion & 0.519 & 0.534 & 0.332 & 0.306 & 0.309 & 0.224 & 0.465 & 0.829 & \\
\hline 9 & Tenacity & 0.698 & 0.718 & 0.309 & 0.309 & 0.341 & 0.326 & 0.613 & 0.567 & 0.837 \\
\hline
\end{tabular}

Note: The square roots of AVE are in bold font on the diagonal, and the correlations among latent constructs are in the lower right triangle

Source: Authors' work 
Table 4

Discriminant validity (Heterotrait-Monotrait Ratio (HTMT))

\begin{tabular}{|c|c|c|c|c|c|c|c|c|c|c|}
\hline & & 1 & 2 & 3 & 4 & 5 & 6 & 7 & 8 & 9 \\
\hline 1 & Analytical & & & & & & & & & \\
\hline 2 & Innovative & 0.832 & & & & & & & & \\
\hline 3 & New Channels & 0.440 & 0.385 & & & & & & & \\
\hline 4 & New Cust Relat & 0.368 & 0.356 & 0.680 & & & & & & \\
\hline 5 & New Markets & 0.439 & 0.510 & 0.784 & 0.860 & & & & & \\
\hline 6 & New Offerings & 0.348 & 0.431 & 0.636 & 0.893 & 0.890 & & & & \\
\hline 7 & Opportunity & 0.871 & 0.667 & 0.390 & 0.373 & 0.456 & 0.364 & & & \\
\hline 8 & Passion & 0.602 & 0.620 & 0.369 & 0.359 & 0.375 & 0.266 & 0.523 & & \\
\hline 9 & Tenacity & 0.793 & 0.816 & 0.339 & 0.356 & 0.411 & 0.381 & 0.686 & 0.642 & \\
\hline
\end{tabular}

Source: Authors' work

After confirming that the measurement model was reliable and valid, the next step was to evaluate the structural relationships. To start the PLS-SEM algorithm, the factor weighting scheme and the stop criterion parameter were set to 10-7 with 5000 maximum iterations was used. Bootstrapping with 5000 sub-samples was used as a nonparametric resampling technique to acquire the empirical t-values. Table 5 presents the results of SEM-PLS testing.

Table 5

Results of hypotheses analysis (model 1)

\begin{tabular}{|c|c|c|c|c|c|}
\hline & $\begin{array}{l}\text { Original } \\
\text { Sample } \\
\text { (0) }\end{array}$ & $\begin{array}{l}\text { Sample } \\
\text { Mean } \\
\text { (M) }\end{array}$ & (STDEV) & $\begin{array}{c}\mathrm{T} \\
\text { Statistics }\end{array}$ & $\begin{array}{c}\text { P } \\
\text { Values }\end{array}$ \\
\hline Opportunity -> New Offerings & 0.163 & 0.170 & 0.105 & 1.551 & 0.121 \\
\hline Opportunity -> New Markets & 0.207 & 0.203 & 0.093 & 2.218 & 0.027 \\
\hline Opportunity -> New Channels & 0.111 & 0.106 & 0.091 & 1.218 & 0.223 \\
\hline Opportunity -> New Cust Relat & 0.169 & 0.171 & 0.103 & 1.639 & 0.101 \\
\hline Analytical -> New Offerings & -0.094 & -0.089 & 0.123 & 0.762 & 0.446 \\
\hline Analytical -> New Markets & -0.051 & -0.043 & 0.112 & 0.458 & 0.647 \\
\hline Analytical -> New Channels & 0.189 & 0.179 & 0.113 & 1.672 & 0.095 \\
\hline Analytical -> New Cust Relat & 0.004 & 0.013 & 0.116 & 0.032 & 0.974 \\
\hline Innovative -> New Offerings & 0.251 & 0.246 & 0.101 & 2.476 & 0.013 \\
\hline Innovative -> New Markets & 0.289 & 0.291 & 0.099 & 2.930 & 0.003 \\
\hline Innovative -> New Channels & 0.100 & 0.106 & 0.103 & 0.973 & 0.331 \\
\hline Innovative -> New Cust Relat & 0.066 & 0.067 & 0.100 & 0.665 & 0.506 \\
\hline Tenacity -> New Offerings & 0.116 & 0.101 & 0.104 & 1.109 & 0.268 \\
\hline Tenacity -> New Markets & -0.011 & -0.021 & 0.101 & 0.104 & 0.917 \\
\hline Tenacity -> New Channels & -0.056 & -0.041 & 0.087 & 0.645 & 0.519 \\
\hline Tenacity -> New Cust Relat & 0.074 & 0.058 & 0.115 & 0.641 & 0.522 \\
\hline Passion -> New Offerings & -0.001 & 0.005 & 0.069 & 0.019 & 0.985 \\
\hline Passion -> New Markets & 0.096 & 0.103 & 0.076 & 1.256 & 0.209 \\
\hline Passion -> New Channels & 0.164 & 0.162 & 0.101 & 1.619 & 0.106 \\
\hline Passion -> New Cust Relat & 0.153 & 0.161 & 0.077 & 1.995 & 0.046 \\
\hline
\end{tabular}

Note: Two-tailed t-values

Source: Authors' work

When it comes to the competence to recognize opportunities, the results indicate a significant impact on innovation in the domain of new market segments $(t=2.218, p<0.05)$, while the impact on other factors is not significant. In other words, the ability to recognize opportunities is associated with new markets, rather than new products, channels, or customer relationships. Analytical skills, on the other 
hand, have a significant influence on new channel innovation ( $t=1.672, p<0.1)$, while having no impact on other dimensions. Passion for work significantly contributes to the innovation of customer relationships ( $t=1.995, p<0.05$ ), but does not affect other dimensions. Innovativeness has a positive effect on new offerings ( $t=2.476, p<0.05$ ) and new markets ( $t=2.930, p<0.05)$. In other words, each competence contributes to one of the dimensions of BMl's new propositions, whereas innovation contributes to two of the dimensions. An innovative manager will contribute to the development of new products and services, as well as the capture of new market segments, by spotting opportunities. Analytical abilities will enable channel innovation, while a passion for the business will facilitate the creation of new customer relationships. Interestingly, tenacity did not have a significant effect on the new propositions of BMI. The explanation for this finding might be due to the necessity to respecify the model, i.e. that tenacity is likely to contribute to the strengthening of other abilities, which in turn impact BMI indirectly. Similarly, Baum et al. (2004) confirmed that tenacity does not contribute to new venture growth, but that it significantly relates to new resource skills.

Figure 1

PLS-SEM results

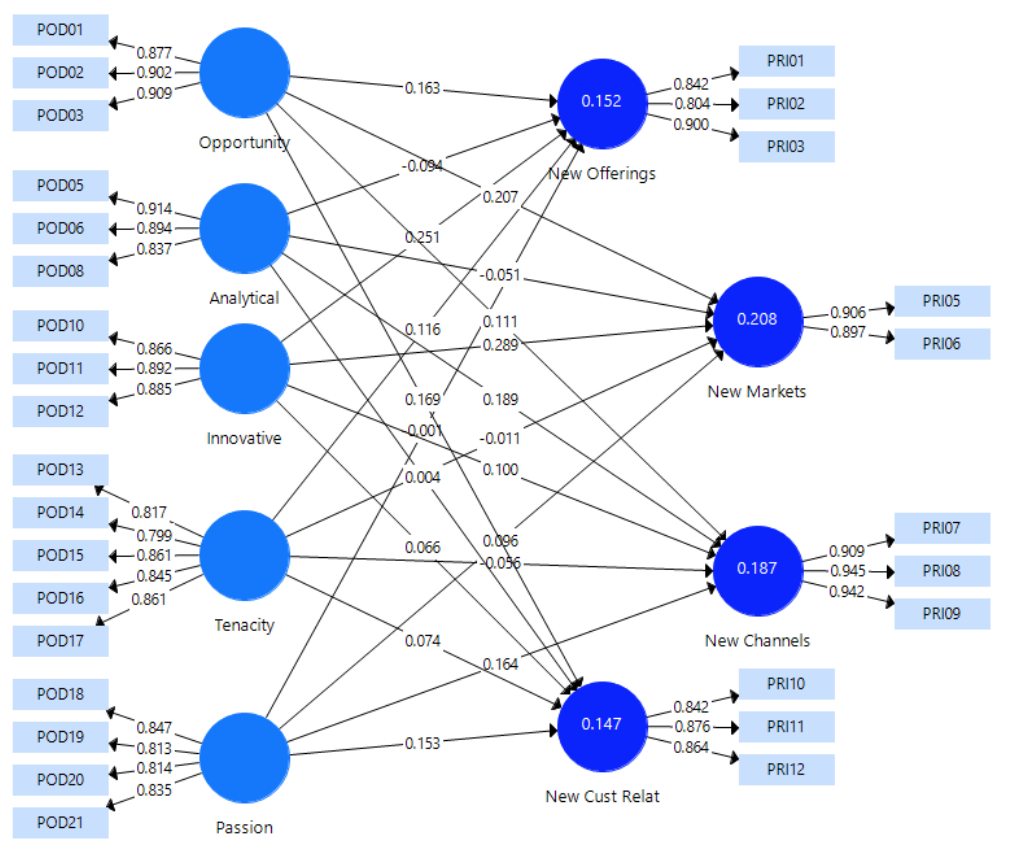

Source: Authors' work

\section{Conclusion}

The purpose of this study was to investigate the relationship between managerial competencies and new BMI propositions in the context of companies operating in a developing nation setting. Managerial competencies of recognizing opportunities, analytical skills, innovativeness, tenacity, and passion for work, as well as their concurrent influence on individual dimensions of BMl's new propositions, namely new offerings, new markets, new channels, and new customer relationships, were investigated. We confirmed that each of the management competencies contributes significantly positively to one dimension of new propositions, whereas innovativeness contributes to two dimensions.

By recognizing opportunities, an innovative manager will help to the creation of new products and services, as well as the capture of new market sectors. Analytical 
skills will enable channel innovation, while a business passion will aid in the formation of new customer relationships. Surprisingly, tenacity had no significant impact on BMl's new propositions. This finding might be explained by the need to re-examine the interrelationships between various competencies of managers, i.e. that tenacity may contribute to the strengthening of other talents, which in turn impacts BMI indirectly. So Baum et al. (2004) confirmed that tenacity does not contribute to the growth of new ventures, but that it is strongly related to new resource skills.

The results of this study confirm that managerial competencies represent a good predictor of organizational capability for innovating a business model. We believe that a good manager possesses various entrepreneurial and managerial competencies and that their combination contributes to new propositions.

\section{References}

1. Anwar, M., Shah, S. Z. A., Khan, S. Z., Khattak, M. S. (2019), "Manager's personality and business model innovation", International Journal of Innovation Management, Vol. 23 No. 7. pp. 1-27.

2. Baum, J. R., Locke, E. A. (2004), "The relationship of entrepreneurial traits, skill, and motivation to subsequent venture growth", Journal of Applied Psychology, Vol. 89 No. 4, pp. 587-598.

3. Bocken, N. M. P., Geradts, T. H. J. (2020), "Barriers and drivers to sustainable business model innovation: Organization design and dynamic capabilities", Long Range Planning, Vol. 53 No. 4, pp. 1-23.

4. Bouncken, R. B., Fredrich, V. (2016), "Business model innovation in alliances: Successful configurations", Journal of Business Research, Vol. 69 No. 9, pp. 3584-3590.

5. Chinwendu, J., Eze, A. N. (2021), "Managerial Competencies Required of Business Education Graduates for Handling Entrepreneurship Challenges in Anambra State, Nigeria", European Journal of Education Studies, Vol. 8 No. 5, pp. 180-196.

6. Clauss, T. (2017), "Measuring business model innovation: conceptualization, scale development, and proof of performance", R and D Management, Vol. 47 No. 3, pp. 385403.

7. Dewald, J., Bowen, F. (2010), "Storm clouds and silver linings: Responding to disruptive innovations through cognitive resilience", Entrepreneurship: Theory and Practice, Vol. 34 No. 1, pp. 197-218.

8. Fornell, C., Larcker, D. F. (1981), "Evaluating Structural Equation Models with Unobservable Variables and Measurement Error", Journal of Marketing Research, Vol. 18, pp. 39-50.

9. Futterer, F., Schmidt, J., Heidenreich, S. (2018), "Effectuation or causation as the key to corporate venture success? Investigating effects of entrepreneurial behaviors on business model innovation and venture performance", Long Range Planning, Vol. 51 No. 1, pp. 64-81.

10. George, G., Bock, A. J. (2011), "The Business Model in Practice and its Implications for Entrepreneurship Research", Entrepreneurship: Theory and Practice, Vol. 35 No. 1, pp. $83-$ 111.

11. Guo, H., Zhao, J., Tang, J. (2013), "The role of top managers' human and social capital in business model innovation", Chinese Management Studies, Vol. 7 No. 3, pp. 447-469.

12. Hair, J. F. J., Black, W. C., Babin, B. J., Anderson, R. E. (2018), "Multivariate Data Analysis", available at: https://doi.org/10.1002/9781119409137.ch4 (1 October 2021)

13. Limaj, E., Bernroider, E. W. N. (2019), "The roles of absorptive capacity and cultural balance for exploratory and exploitative innovation in SMEs", Journal of Business Research, Vol. 94 No. October, pp. 137-153.

14. Lumpkin, G. T., Steier, L., Wright, M. (2011), "In Family Business Business and Strategic", Strategic Entrepreneurship Journal, Vol. 306, pp. 285-306.

15. Man, T. (2002), "The competitiveness of small and medium enterprises: A conceptualization with focus on entrepreneurial competencies", Journal of Business Venturing, Vol. 17 No. 2, pp. 123-142. 
16. Man, T. W. Y., Lau, T., Snape, E. (2008), "Entrepreneurial Competencies and the Performance of Small and Medium Enterprises: An Investigation through a Framework of Competitiveness", Journal of Small Business and Entrepreneurship, Vol. 21 No. 3, pp. 257276.

17. Mitchelmore, S., Rowley, J. (2010), "Entrepreneurial competencies: A literature review and development agenda", International Journal of Entrepreneurial Behaviour \& Research, Vol. 16 No. 2, pp. 92-111.

18. Smith, W. K., Binns, A., Tushman, M. L. (2010), "Complex business models: Managing strategic paradoxes simultaneously", Long Range Planning, Vol. 43 No. 2-3, pp. 448-461.

19. Spieth, P., Schneider, S. (2016), "Business model innovativeness: designing a formative measure for business model innovation", Journal of Business Economics, Vol. 86 No. 6, pp. 671-696.

20. Zott, C., Amit, R. (2010), "Business model design: An activity system perspective", Long Range Planning, Vol. 43 No. 2-3, pp. 216-226.

21. Zott, C., Amit, R., Massa, L. (2011), "The business model: Recent developments and future research", Journal of Management, Vol. 37 No. 4, pp. 1019-1042.

\section{About the authors}

Dr. Lejla Turulja is an associate professor at the Department of Management and Information Technology (MIT) at the School of Economics and Business (SEBS), University of Sarajevo. She holds a Ph.D. from the SEBS, and her dissertation deals with the impact of knowledge, technology, and innovation on the company's success in the New economy. In her scientific work, she focuses on various aspects of information technology management, from information systems, e-business, innovation, knowledge management to technology transfer. She has published the results of her research work in prominent scientific journals; she is the author or coauthor of several scientific papers published in indexed journals and conferences, several books, and book chapters. She has been engaged as an expert and/or researcher on several international and national projects. She gained international experience during study visits to European universities, including Vienna University of Economics and Business and the Wroctaw University of Economics. Besides, as a U.S. State Department Fellow, she has been a guest at Northwestern University in Chicago, USA. The author can be contacted at lejla.turulja@efsa.unsa.ba

Selma Smajlovic works as the Assistant professor at the Faculty of Economics, University in Tuzla (Bosnia and Herzegovina). Recipient of the University in Tuzla Gold Medal. In eleven years of academic career, she has gone through associate titles, namely teaching assistant and senior teaching assistant in the research field of management and business. Currently, in the Assistant Professor role, she is teaching at first and second study levels in the Faculty of Economics. She graduated from the Faculty of Economics, University in Sarajevo, where she got her Ph.D. with the topic "Influence of business model innovations on the firm success performances". Her professional development was conducted in Croatia and Slovenia. Her research interests are entrepreneurship, innovations, business model management, competencies, and consulting. As author and co-author, she has published 12 scientific and research papers in recognized journals and presented them at international and national conferences. She was a member of the GEM (Global Entrepreneurship Monitor) national team of Bosnia and Herzegovina. Notable engagements include the role of teacher and consultant on projects financed by USAID and EU and leading role and participation in ten international and domestic research projects. The author can be contacted at email selma.smajlovic@untz.ba 